Syntax Idea : P-ISSN: 2684-6853 E-ISSN : 2684-883X

Vol. 2, No. 3 Maret 2020

\title{
PENERAPAN METODE PEMBELAJARAN THINK TALK WRITE UNTUK MENINGKATKAN PEMAHAMAN KONSEP SISWA PADA MATERI MENGONSUMSI MAKANAN DAN MINUMAN YANG HALAL DAN MENJAUHI YANG HARAM DI SMP NEGERI 3 CIAWIGEBANG
}

\author{
Nana Supriatna \\ SMP Negeri 3 Ciawigebang \\ Email: nana3supriatna@gmail.com
}

\begin{abstract}
Abstrak
Berdasarkan hasil studi pendahuluan pemahaman konsep siswa masih rendah, hal ini terbukti dari hasil tes sebagian besar siswa kelas VIII SMP Negeri 3 Ciawigebang Kabupaten Kuningan yaitu sebesar $75 \%$ memperoleh nilai Pendidikan Agama Islam di bawah KKM yaitu 75. Rumusan masalah dalam penelitian ini ialah apakah penerapan metode pembelajaran Think Talk Write dapat meningkatkan pemahaman konsep siswa pada materi Mengonsumsi Makanan serta Minuman yang Halal dan Menjauhi yang Haram di SMP Negeri 3 Ciawigebang Kabupaten Kuningan ?. Tujuan penelitian adalah untuk mengetahui penerapan metode pembelajaran Think Talk Write dapat meningkatkan pemahaman konsep siswa pada materi Mengonsumsi Makanan dan Minuman yang Halal dan Menjauhi yang Haram di SMP Negeri 3 Ciawigebang Kabupaten Kuningan. Metode penelitian yang digunakan ialah penelitian tindakan kelas. Setting penelitian ini adalah siswa kelas VIII SMP Negeri 3 Ciawigebang Kabupaten Kuningan yang berjumlah 32 siswa. Teknik pengumpulan data dalam penelitian ini adalah tes dilaksanakan setiap siklus berupa tes tertulis pilihan ganda. Berdasarkan data pemahaman siswa dalam pembelajaran Pendidikan Agama Islam dengan penerapan metode pembelajaran Think Talk Write pada siklus 1 di kelas VIII SMP Negeri 3 Ciawigebang Kabupaten Kuningan memperoleh nilai terendah 30, nilai tertinggi 75 dan memperoleh nilai rata-rata 56,41 berada di bawah Kriteria Ketuntasan Minimal (KKM) yang sudah diterapkan sebesar 75. Artinya penerapan metode pembelajaran Think Talk Write belum berhasil meningkatkan pemahaman siswa untuk pembelajaran Pendidikan Agama Islam i kelas VIII SMP Negeri 3 Ciawigebang Kabupaten Kuningan. pemahaman siswa dalam pembelajaran Pendidikan Agama Islam dengan penerapan metode pembelajaran Think Talk Write pada siklus 2 di kelas VIII SMP Negeri 3 Ciawigebang Kabupaten Kuningan memperoleh nilai terendah 65, nilai tertinggi 95 dan memperoleh nilai rata-rata 83,59 berada di atas Kriteria Ketuntasan Minimal (KKM) yang telah ditetapkan sebesar 75. Artinya penerapan metode pembelajaran Think Talk Write sangat berhasil meningkatkan pemahaman siswa dalam pembelajaran Pendidikan Agama Islam di kelas VIII SMP Negeri 3 Ciawigebang Kabupaten Kuningan.
\end{abstract}

Kata kunci: metode pembelajaran Think Talk Write, pemahaman siswa 


\section{Pendahuluan}

Pembelajaran ialah suatu usaha untuk membuat peserta didik belajar atau suatu kegiatan untuk membelajarkan peserta didik (Agustina \& Adesti, 2019). Menurut (Ansari, 2003) "Metode pembelajaran Think Talk Write ialah sebuah pembelajaran yang di awali dengan berpikir melalui referensi bacaan (menyimak, mengkritisi, serta alternative solusi), hasil bacaannya di aplikasikan dengan presentasi, diskusi, kemudian menyusun laporan akhir presentasi".

Hal ini seadan dengan pendapat di atas, (Yamin, 2008) mengemukakan bahwa "Metode pembelajaran Think Talk Write adalah pembelajaraan di mana siswa diberikan kesempatan terhadap siswa dalam mengawali belajar dengan memahami permasalahan terlebih dahulu, kemudian terikat secara aktif dalam diskusi kelompok, serta akhirnya menuliskan dengan bahasa sendiri hasil belajar yang diperolehnya".

Menurut (Suherman, 2003) langkah-langkah metode pembelajaran Think Talk Write adalah sebagai berikut :

1) Proses pembelajaran think-talk-write diawali dengan mengajukan pertanyaan yang untuk hal ini berupa soal yang memuat suatu permasalahan yang terkait dengan materi pelajaran

2) Meminta siswa menyelesaikan soal yang sudah diberikan. Pengerjaan untuk pertama soal tersebut dikerjakan secara individu. Selama kegiatan belajar berlangsung guru berkeliling untuk mengamati kegiatan siswa

3) Siswa diminta agar mendiskusikan jawaban masing-masing siswa sekelompoknya sehingga diperoeh satu jawaban yang tepat menurut kelompok masing-masing

4) Sesudah soal dikerjakan dengan kelompok, guru meminta beberapa siswa untuk mempresentasikan jawaban kelompok mereka di hadapan kelas

5) Guru memberikan kesempatan terhadap kelompok lain dalam menanggapi hasil diskusi kelompok yang di hadapan kelas. Apabila ada jawaban kelompok yang berbeda guru mempersilahkan kelompok lainnya untuk mempresentasikan jawaban mereka serta memberikan penjelasan kepada yang lainnya bahwa jawaban mereka yang lebih tepat

6) Guru memberikan penjelasan kepada siswa jawaban mana yang paling tepat serta menunjukkan cara penyelesaian yang tepat serta memberikan waktu kepada siswa untuk mencatat hasil yang diperoleh dari diskusi antar kelompok

7) Setelah proses pembelajaran think-talk-write, kemudian dilanjutkan dengan pelaksanaan evaluasi. Siswa diberikan soal yang berkaitan dengan materi pelajaran. Jumlah soal keseluruhan sebanyak lima butir berbentuk uraian. Siswa diberikan waktu 30 menit dalam menyelesaikan soal evaluasi. Kegiatan pembelajaran diakhiri dengan pembahasan yang menurut siswa sangat sulit

8) Pada kegiatan akhir guru menutup pelaksanaan pembelajaran dengan membimbing siswa menyimpulkan langkah-langkah yang biasa digunakan dalam penyelesaian soal yang sudah dibahas secara bersama.

Menurut (Ansari, 2003) kelebihan metode pembelajaran Think Talk Write ialah sebagai berikut :

1) Membantu siswa untuk mengkonstruksi pengetahuannya sendiri sehingga pemahaman konsep siswa jauh lebih baik

2) Siswa bisa mengkomunikasikan atau mendiskusikan pemikirannya bersama temannya 
3) Siswa saling membantu serta saling bertukar pikiran

4) Membantu siswa untuk memahami materi yang diajarkan

5) Melatih siswa dalam menuliskan hasil diskusinya dalam bentuk tulisan secara sistematis

6) Siswa akam lebih memahami materi

7) Membantu siswa untuk mengkomunikasikan ide-idenya dalam bentuk tulisan.

Menurut (Vestari, 2009) "Pemahaman konsep ialah kemampuan menangkap pengertian-pengertian seperti mampu mengungkap suatu materi yang disajikan kedalam bentuk yang lebih dipahami, mampu memberikan interpretasi serta mampu mengaplikasikannya".

Hal ini selaras dengan pendapat di atas, (Daryanto, 1999) mengemukakan bahwa : Penguasan konsep merupakan tingkatan hasil belajar siswa sehingga bisa mendefinisikan atau menguraikan sebagian atau mendefinisikan bahan pelajaran dengan menggunakan kalimat sendiri. Dengan kemampuan siswa menguraikan atau mendefinisikan, maka siswa tersebut sudah mengerti konsep atau prinsip dari suatu pelajaran meskipun penjelasan yang diberikan mempunyai susunan kalimat yang tidak selaras dengan konsep yang diajukan tetapi sama artinya.

Menurut (Daryanto, 1999) indikator-indikator yang menunjukkan pemahaman konsep seperti hal-hal berikut:

1) Menyatakan ulang sebuah konsep

2) Mengklasifikasikan obyek-obyek menurut sifat-sifat tertentu (sesuai dengan konsepnya)

3) Memberi contoh serta non contoh dari konsep

4) Menyajikan konsep dalam berbagai bentuk representasi

5) Mengembangkan syarat perlu serta syarat cukup suatu konsep

6) Menggunakan, memanfaatkan, serta memilih prosedur atau operasi tertentu

7) Mengaplikasikan konsep atau algoritma dalam pemecahan masalah

Pendapat lain tentang indikator pemahaman konsep, (Sanjaya, 2006) mengemukakan bahwa indikator yang dimuat untuk pemahaman konsep meliputi :

1) Mampu menguraikan secara verbal mengenai apa yang sudah diraihnya

2) Mampu mensajikan situasi matematika kedalam berbagai metode serta mengetahui perbedaan

3) Mampu mengelompokkan objek-objek berdasarkan dipenuhi atau tidaknya persyaratan yang membentuk konsep tersebut

4) Mampu menerapkan hubungan antara konsep serta prosedur

5) Mampu memberikan contoh serta contoh kontra dari konsep yang dipelajari

6) Mampu menerapkan konsep

7) Mampu mengembangkan konsep yang telah dipelajari. 
Adapun kerangka berpikir dalam penelitian ini dapat diilustrasikan sebagai berikut :

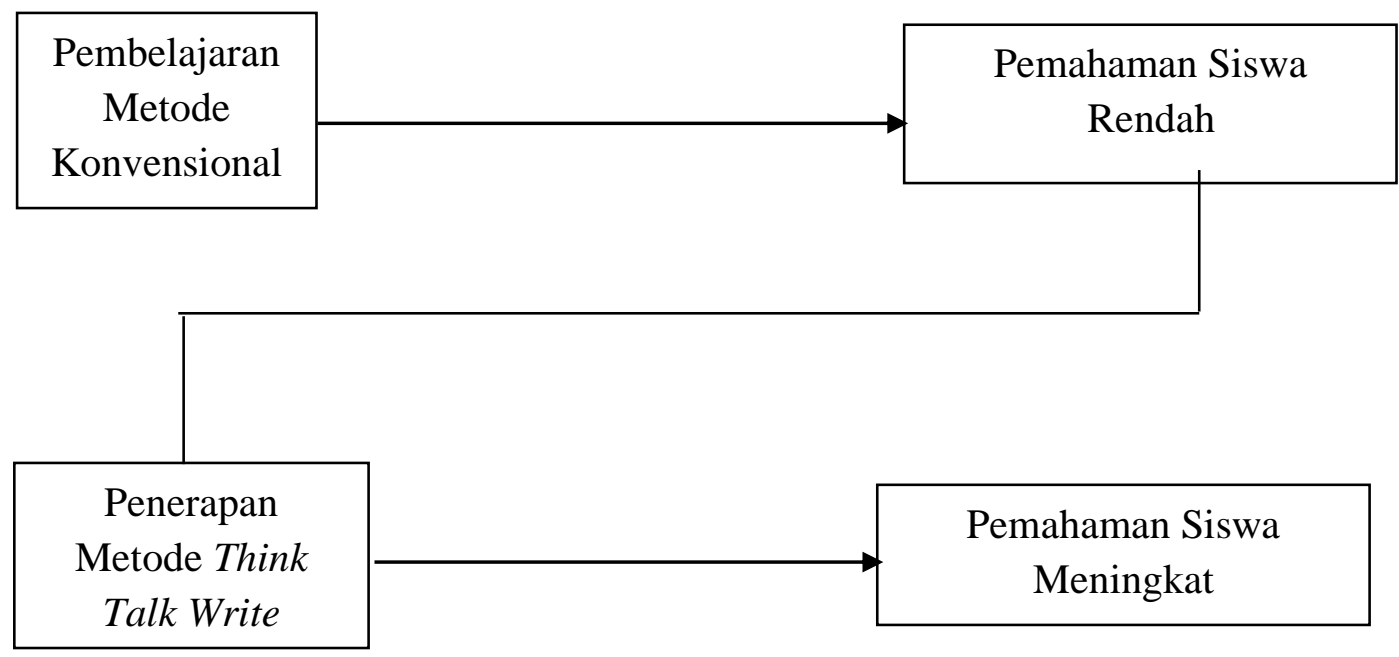

Berdasarkan kerangka berpikir di atas peneliti mengajukan hipotesis sebagai berikut : "Penerapan metode pembelajaran Think Talk Write dapat meningkatkan pemahaman konsep siswa pada materi Mengonsumsi Makanan dan Minuman yang Halal dan Menjauhi yang Haram di SMP Negeri 3 Ciawigebang Kabupaten Kuningan”.

\section{Metode Penelitian}

Setting penelitian ini adalah SMP Negeri 3 Ciawigebang Kabupaten Kuningan dengan subjek penelitian yaitu siswa kelas VIII yang berjumlah 32 siswa. Karakteristik siswa kelas VIII dipilah sebagai subjek penelitian karena sangat beragam dari tingkat pendidikan orang tua siswa, status ekonomi keluarga, tingkat kecerdasan siswa, serta lingkungan tempat tinggal siswa. Tingkat kecerdasan siswa sangat beragam mulai dari siswa yang memiliki kecerdasan rendah, sedang serta tinggi sehingga siswa tersebut membutuhkan bimbingan dari guru.

Penelitian ini dilakukan dengan pendekatan penelitian tindakan kelas. Desain penelitian alur (siklus) PTK ialah desain penelitian siklus PTK secara konseptual.

\section{Hasil dan Pembahasan}

\section{A. Deskripsi Pembelajaran Siklus 1}

Berdasarkan hasil pengamatan terhadap aktivitas mengajar guru dalam pembelajaran yang meliputi kegiatan awal, kegiatan inti, serta kegiatan akhir dengan penerapan metode pembelajaran Think Talk Write dalam pembelajaran Pendidikan Agama Islam siklus pertama pada umumnya termasuk kategori cukup. Dengan demikian aktivitas mengajar guru dalam pembelajaran belum melakukan tahapan proses pembelajaran Pendidikan Agama Islam dengan penerapan metode pembelajaran Think Talk Write. Analisis aktivitas mengajar guru dalam proses pembelajaran masih ada yang harus diperbaiki yaitu : guru kurang memberikan kesempatan kepada siswa untuk bertanya serta mengemukakan pendapat, guru 
kurang memberikan bimbingan kepada siswa dalam menyelesaikan tugas belajar, guru tidak mewujudkan interaksi edukatif serta komunikasi yang baik antara guru dengan siswa maupun antar siswa dalam kelompok belajar.

Berdasarkan hasil pengamatan terhadap aktivitas siswa dalam pembelajaran Pendidikan Agama Islam dengan penerapan metode pembelajaran Think Talk Write masih rendah, hal ini ditunjukkan siswa kurang terlibat aktif dalam kegiatan apersepsi tentang materi pelajaram, kurang aktif dalam penggunaan alat peraga, siswa kurang aktif dalam kegiatan pembelajaran, pengusaan materi pembelajaran kurang dan siswa kurang aktif dalam menyimpulkan materi pembelajaran. Siswa memahami tujuan dan langkah-langkah pembelajaran, siswa dibimbing dalam pembelajaran, mengajukan pertanyaan, mengerjakan soal evaluasi dan merespon serta melaksanakan tugas yang diberikan oleh guru termasuk kategori cukup.

Data yang didapat hasil dari tes pada siklus 1 menunjukkan bahwa pemahaman siswa dalam pembelajaran Pendidikan Agama Islam dengan penerapan metode pembelajaran Think Talk Write pada siklus 1 di kelas VIII SMP Negeri 3 Ciawigebang Kabupaten Kuningan memperoleh nilai terendah 30, nilai tertinggi 75 dan memperoleh nilai rata-rata 56,41 berada di bawah Kriteria Ketuntasan Minimal (KKM) yang telah ditetapkan sebesar 75. Artinya penerapan metode pembelajaran Think Talk Write belum berhasil meningkatkan pemahaman siswa dalam pembelajaran Pendidikan Agama Islam i kelas VIII SMP Negeri 3 Ciawigebang Kabupaten Kuningan. Kegagalan pembelajaran siklus 1 disebabkan guru kurang memberikan kesempatan kepada siswa untuk bertanya dan mengemukakan pendapat, guru kurang memberikan bimbingan kepada siswa dalam menyelesaikan tugas belajar, guru tidak menciptakan interaksi edukatif dan komunikasi yang baik antara guru dengan siswa maupun antar siswa dalam kelompok belajar, siswa merasa kesulitan dalam mengamati dan menganalisis materi pelajaran, sebagian besar siswa mengalami kesulitan dalam menyelesaikan lembar kerja siswa berkaitan dengan materi pelajaran.

\section{B. Deskripsi Pembelajaran Siklus 2}

Berdasarkan hasil pengamatan terhadap aktivitas mengajar guru dalam pembelajaran yang terdiri dari kegiatan awal, kegiatan inti, dan kegiatan akhir dengan penerapan metode pembelajaran Think Talk Write dalam pembelajaran Ilmu Pendidikan Agama Islam siklus kedua pada umumnya termasuk kategori baik. Dengan demikian aktivitas mengajar guru dalam pembelajaran sudah baik dalam melakukan tahapan proses pembelajaran Pendidikan Agama Islam tentang Mengonsumsi Makanan dan Minuman yang Halal dan Menjauhi yang Haram dengan penerapan metode pembelajaran Think Talk Write sudah maksimal. Analisis aktivitas mengajar guru dalam proses pembelajaran diantaranya guru memberikan kesempatan kepada siswa untuk bertanya dan mengemukakan pendapat, guru memberikan bimbingan kepada siswa dalam menyelesaikan tugas belajar, guru menciptakan interaksi edukatif dan komunikasi yang baik antara guru dengan siswa maupun antar siswa dalam kelompok belajar. 
Berdasarkan hasil pengamatan terhadap aktivitas siswa dalam pembelajaran Pendidikan Agama Islam dengan penerapan metode pembelajaran Think Talk Write tinggi, hal ini ditunjukkan siswa terlibat aktif dalam kegiatan apersepsi tentang materi pelajaran, aktif dalam penggunaan alat peraga, siswa aktif dalam kegiatan pembelajaran, pengusaan materi pembelajaran baik dan siswa aktif dalam menyimpulkan materi pembelajaran, siswa memahami tujuan dan langkahlangkah pembelajaran, mengerjakan soal evaluasi dan merespon serta melaksanakan tugas yang diberikan oleh guru termasuk baik. Sedangkan siswa dibimbing dalam pembelajaran, mengajukan pertanyaan termasuk kategori baik sekali.

Data yang didapat hasil dari tes pada siklus 2 menunjukkan bahwa pemahaman siswa dalam pembelajaran Pendidikan Agama Islam dengan penerapan metode pembelajaran Think Talk Write pada siklus 2 di kelas VIII SMP Negeri 3 Ciawigebang Kabupaten Kuningan memperoleh nilai terendah 65, nilai tertinggi 95 dan memperoleh nilai rata-rata 83,59 berada di atas Kriteria Ketuntasan Minimal (KKM) yang telah ditetapkan sebesar 75. Artinya penerapan metode pembelajaran Think Talk Write sangat berhasil meningkatkan pemahaman siswa dalam pembelajaran Pendidikan Agama Islam di kelas VIII SMP Negeri 3 Ciawigebang Kabupaten Kuningan. Keberhasilan pembelajaran siklus 2 disebabkan guru memberikan kesempatan kepada siswa untuk bertanya dan mengemukakan pendapat, guru memberikan bimbingan kepada siswa dalam menyelesaikan tugas belajar, guru menciptakan interaksi edukatif dan komunikasi yang baik antara guru dengan siswa maupun antar siswa dalam kelompok belajar, siswa dapat mengamati dan menganalisis materi, sebagian besar siswa dapat menyelesaikan lembar kerja siswa berkaitan dengan materi pelajaran.

\section{Kesimpulan}

Berdasarkan hasil penelitian dan pembahasan di atas, maka penulis menarik kesimpulan sebagai berikut :

1. Penerapan metode pembelajaran Think Talk Write pada materi Mengonsumsi Makanan dan Minuman yang Halal dan Menjauhi yang Haram di SMP Negeri 3 Ciawigebang Kabupaten Kuningan termasuk kategori baik

2. Pemahaman konsep siswa pada materi Mengonsumsi Makanan dan Minuman yang Halal dan Menjauhi yang Haram di SMP Negeri 3 Ciawigebang Kabupaten Kuningan pada siklus 1 memperoleh nilai rata-rata 56,63 sedangan siklus 2 memperoleh nilai rata-rata 83,59

3. Metode pembelajaran Think Talk Write dapat meningkatkan pemahaman konsep siswa, hal ini dibuktikan pada siklus 1 memperoleh nilai rata-rata 56,63 berada di bawah KKM, sedangkan siklus 2 memperoleh nilai rata-rata 83,38 berada di atas KKM. 


\section{BIBLIOGRAFI}

Agustina, Nora, \& Adesti, Anita. (2019). Pengembangan Modul Mata Kuliah Strategi Belajar dan Pembelajaran Pada FKIP-Universitas Baturaja. Syntax Literate; Jurnal Ilmiah Indonesia, 4(9), 83-93.

Ansari. (2003). Model-model Pembelajaran Inovatif. Semarang: UNNES.

Daryanto, H. M. (1999). Evaluasi pendidikan: komponen MKDK. PT Rineka Cipta.

Sanjaya, Wina. (2006). Strategi pembelajaran berorientasi standar proses pendidikan.

Suherman, Erman. (2003). Strategi pembelajaran matematika kontemporer. Bandung: Jica.

Vestari, D. (2009). Model pembelajaran berbasis fenomena dengan pendekatan inkuiri terbimbing untuk meningkatkan pemahaman konsep pembiasan cahaya dan keterampilan generik sains siswa SMP. SPS: Universitas Pendidikan Indonesia: Bandung.

Yamin, Martinis. (2008). Paradigma pendidikan konstruktivistik: implementasi KTSP dan UU no. 14 tahun 2005 Tentang Guru dan Dosen. Gaung Persada Press. 